ADVANCE RESEARCH JOURNAL OF SOCIAL SCIENCE
$\begin{gathered}\text { RESEARCH } \\ \text { ARTICLE }\end{gathered}$
$\begin{gathered}\text { Volume } 8 \mid \text { Issue } 2 \mid \text { December, 2017 | 239-247 } \\ \text { DOI: 10.15740/HAS/ARJSS/8.2/239-247 }\end{gathered}$

\title{
Study of socio-personal determiants and level of loneliness of undergraduate students in Ludhiana district
}

Rajinder Kaur* and Vandana Kanwar

Department of Human Development and Family Studies, College of Home Science, Punjab Agricultural University, LUDHIANA (PUNJAB) INDIA

(Email : kanwarvandana@pau.edu)

\section{ARTICLE INFO :}

$\begin{array}{lll}\text { Received } & : & 26.07 .2017 \\ \text { Revised } & : & 13.10 .2017 \\ \text { Accepted } & : & 28.10 .2017\end{array}$

\section{KeY WORDS :}

Perceived loneliness, Sociopersonal, Gender, Undergraduates, Industrialization, Globalization

\section{HOW TO CITE THIS ARTICLE :}

Kaur, Rajinder and Kanwar, Vandana (2017). Study of socio-personal determiants and level of loneliness of undergraduate students in Ludhiana district. Adv. Res. J. Soc. Sci., 8 (2) : 239247, DOI: 10.15740/HAS/ARJSS/8.2/ 239-247.

*Author for correspondence

\begin{abstract}
The present study was conducted on undergraduate students of Punjab Agricultural University, Ludhiana. Total sample comprised of 400 students studying in four different colleges. General information sheet was used to procure the necessary information on socio-personal characteristics of the respondents. Perceived loneliness scale developed by Jha (1971) was used to assess the perceived loneliness of students. Results indicated that students of less educated parents perceived more loneliness followed by parents who were educated upto graduation level. In all colleges majority of the respondents' mothers were homemakers and majority of fathers were engaged in government services. In all colleges majority of students were belonged to nuclear families except in College of Agricultural Engineering and Technology and majority of students were from moderate size of families. Students studying in College of Agricultural Engineering and Technology perceived less loneliness as compared to other colleges. In rest of the three colleges, College of Home Science perceived more loneliness followed by students in College of Basic Sciences and Humanities and College of Agriculture. Gender-based perceived loneliness among respondents results concluded that in all colleges majority of male respondents perceived less level of loneliness as compared to females, except in COAE and $\mathrm{T}$ where both male and female respondents perceived less level of loneliness.
\end{abstract}

